\title{
High serum endostatin levels in Down syndrome: implications for improved treatment and prevention of solid tumours
}

\author{
Todd S Zorick ${ }^{1}$, Zan Mustacchi ${ }^{2}$, Silvia Yumi Bando ${ }^{3}$, Mayana Zatz ${ }^{1}$, \\ Carlos Alberto Moreira-Filho ${ }^{3}$, Björn Olsen ${ }^{4}$ and Maria Rita Passos-Bueno ${ }^{*, 1}$
}

${ }^{1}$ Center for the Study of the Human Genome, Department of Biology, University of São Paulo, São Paulo, Brazil; ${ }^{2}$ Hospital Darcy Vargas, São Paulo, SP, Brazil; ${ }^{3}$ Department of Immunology, University of São Paulo, São Paulo, Brazil; ${ }^{4}$ Department of Cell Biology, Harvard Medical School, Boston, Massachusetts, USA

We report here a comparison of serum endostatin levels in Down syndrome patients to normal control subjects. We analysed serum samples from 35 patients with Down syndrome and 54 normal control subjects and found that although serum levels of endostatin vary widely in a normal human population, serum endostatin levels are significantly elevated in patients with Down syndrome. This result may explain the relative decrease in incidence of various solid tissue tumours observed in Down syndrome, given the role of endostatin as a potent inhibitor of tumour-induced angiogenesis in both human and animal models. Based upon these data, we propose that an increase of about one-third of normal endostatin serum levels may represent an effective therapeutic dose to significantly inhibit many solid tumours. European Journal of Human Genetics (2001) 9, 811-814.

Keywords: endostatin; Down syndrome; cancer; ELISA

\section{Introduction}

Down syndrome (DS) is most commonly caused by duplication of one of the copies of chromosome 21, resulting in trisomy for this chromosome. DS patients are characterised by mental impairment that is frequently associated with dysmorphic features, cardiac abnormalities, early onset Alzheimer disease, gonadal deficiency, and an increased risk for certain leukaemias and immunological deficiencies. ${ }^{1}$ Recent advances in the treatment for these patients have resulted in an increase in the average life span in DS that has allowed an evaluation of solid tissue cancer incidence, which more commonly occur in aged populations. Surprisingly, although some types of cancer (particularly many types of leukaemia, gonadal, and soft tissue cancers) are relatively more common, solid tumours as a whole have been found to have a decreased incidence in DS. ${ }^{2-4}$ This finding has led to

*Correspondence: Maria Rita Passos-Bueno, Center for the Study of the Human Genome, Rua do Matão, 277, Dept Biologia, Universidade de São Paulo, São Paulo, SP, Brazil, 05508-900. Tel: +55 11 38187563;

Fax: +55 11 38187419; E-mail: passos@ib.usp.br

Received 13 March 2001; revised 10 July 2001; accepted 19 August 2001 the speculation of possible 'tumour suppressor' genes for solid tumours on chromosome $21 .^{2-5}$ Indeed, loss of heterozygosity has been observed for specific regions of chromosome 21 in several solid tumours. ${ }^{6-8}$ However, although chromosome 21 has been completely sequenced, no recognised tumour suppressor genes have yet been described. ${ }^{5}$ We hypothesise that the decreased incidence of solid tumours in individuals with DS may be due to increased dosage of one or more chromosome 21 gene products that might participate in a common mechanism involved in the growth of various solid tumours.

Endostatin is a soluble $20 \mathrm{kd}$ cleavage product of collagen XVIII, which is encoded by the COL18A1 gene at 21q22.3.9,10 It has recently been shown that endostatin is a potent angiogenesis inhibitor for many different types of solid tissue tumours in both human and animal models. Endostatin is also currently being aggressively pursued as a candidate for cancer therapy in humans. ${ }^{9,11,12}$ The COL18A1 gene was found to be widely expressed in mice and humans. ${ }^{10,13,14}$ The production and liberation of endostatin is still poorly understood, but it has been found to be expressed in some differentiated tissues (eg kidney and liver) and freely 
circulating in serum. ${ }^{9,15,16}$ These observations, combined with the emerging data on endostatin as a potential tumour angiogenesis inhibitor prompted us to verify whether patients with DS had an increased serum level of endostatin compared with normal control subjects.

\section{Materials and methods \\ Human subjects}

All human subjects used for this study were enrolled voluntarily, under their own consent or with the consent of responsible family members when appropriate (ie for minors and patients with DS). The control individuals (22 males, 32 females) were healthy parents of patients with neuromuscular disorders seen at our Center. Down syndrome patients (16 males, 19 females) were ascertained at the Hospital Darcy Vargas, São Paulo. The diagnosis was established based on clinical evaluation and confirmed by karyotype analysis. Clinical data from most of these patients are described in Table 1. Blood samples were collected by venipuncture in EDTA containing tubes, always in the morning, and serum was separated and stored at $-70^{\circ} \mathrm{C}$ for future use.

\section{ELISA}

ELISA for serum endostatin was performed using a commercially available assay (Accucyte, Cytimmune Sciences, Inc., College Park, MD, USA) according to the manufacturer's instructions for usage. All measurements were performed in duplicate to ensure the accuracy of the data collected. The kit used has a sensitivity of $2 \mathrm{ng} / \mathrm{ml}$, and typical interassay and intra-assay variances were $10 \%$ or less. Readings were performed on a Titertek Multiskan PLUS plate reader (EFLAB, Finland) at $492 \mathrm{~nm}$ wavelength according to the manufacturer's instructions.

\section{Statistical analysis}

Statistical analysis of the serum endostatin levels from patients and control subjects was analysed using the program JMP running on an Apple Macintosh G3 computer.

\section{Results}

We observed that endostatin levels vary widely among normal individuals, ranging from 4 to $40 \mathrm{ng} / \mathrm{ml}$ (Figure 1; Table 1). We found a highly significant difference in the average serum endostatin concentration between Down syndrome and control subjects $(38.6 \pm 20.1$ for DS, $20.3 \pm 11.5$ for normal subjects, data reported as mean \pm SD in $\mathrm{ng} / \mathrm{ml} ; P<0.0001$ by Wilcoxon/ Kruskal-Wallis tests; see Figure 1 and Tables 1 and 2). Statistical analysis revealed no significant difference in endostatin levels by sex for either the control group or DS population (F ratio 0.4141, $P>0.05$ for both groups; see Table 2). The average age for the control group was $17.9 \pm 12.9$ years, while for the DS patients the average age was $11.4 \pm 4.6$ years. Linear regression of
Table 1 Endostatin levels for Down patients included in the study, with age, sex, and associated physical abnormalities

\begin{tabular}{|c|c|c|c|c|}
\hline Registry & Age & Sex & Endostatin $(\mathrm{ng} / \mathrm{ml})$ & Other abnormalities \\
\hline F1025 & 14 & $M$ & 7 & HST \\
\hline F1026 & 18 & $\mathrm{M}$ & 28 & OCSB \\
\hline F1027 & 17 & $\mathrm{~F}$ & 44 & $\mathrm{HT}$ \\
\hline F1028 & 12 & $\mathrm{M}$ & 42 & - \\
\hline F1030 & 7 & $\mathrm{~F}$ & 35 & n.d. \\
\hline F1031 & 10 & $\mathrm{~F}$ & 64 & n.d. \\
\hline F1032 & 4 & $\mathrm{~F}$ & 8 & VSD \\
\hline F1033 & 7 & $\mathrm{~F}$ & 11 & n.d. \\
\hline F1034 & 6 & $\mathrm{~F}$ & 6 & SGB \\
\hline F1038 & 13 & $\mathrm{~F}$ & 44 & OS, DA, HT, AP \\
\hline F1039 & 6 & $\mathrm{~F}$ & 48 & n.d. \\
\hline F1040 & 17 & $\mathrm{~F}$ & 64 & AAI \\
\hline F1041 & 6 & $\mathrm{M}$ & 16 & MVP, HT, UC \\
\hline F1042 & 10 & $\mathrm{M}$ & 60 & OAVC, BCO \\
\hline F1043 & 14 & $\mathrm{~F}$ & 29 & n.d. \\
\hline F1044 & 11 & $\mathrm{M}$ & 8 & n.d. \\
\hline F1046 & 11 & $\mathrm{M}$ & 60 & SC, CS \\
\hline F1047 & 11 & $\mathrm{M}$ & 72 & $\mathrm{AC}, \mathrm{AAl}$ \\
\hline F1048 & 4 & $\mathrm{M}$ & 76 & ASD, GERD \\
\hline F1059 & 18 & $\mathrm{M}$ & 44 & - \\
\hline F1060 & 16 & $\mathrm{~F}$ & 39 & PVI, TVI, AAI \\
\hline F1061 & 17 & $\mathrm{M}$ & 20 & AUM \\
\hline F1062 & 11 & $\mathrm{~F}$ & 29 & ASD, TVI \\
\hline F1063 & 12 & $\mathrm{~F}$ & 48 & n.d. \\
\hline F1064 & 11 & $\mathrm{M}$ & 28 & C1AAH \\
\hline F1067 & 12 & $\mathrm{~F}$ & 6 & VSD, PDA \\
\hline F1068 & 7 & $\mathrm{~F}$ & 52 & ASD, HT \\
\hline F1069 & 14 & $\mathrm{M}$ & 48 & ASD \\
\hline F1070 & 16 & $\mathrm{~F}$ & 38 & HST, DM \\
\hline F1071 & 10 & $\mathrm{~F}$ & 40 & SGB, HT, PP \\
\hline F1072 & 15 & $\mathrm{M}$ & 68 & - \\
\hline F1073 & 12 & $\mathrm{~F}$ & 60 & AVI, TVI \\
\hline F1075 & 9 & $\mathrm{~F}$ & 36 & n.d. \\
\hline F1076 & 5 & $\mathrm{M}$ & 40 & n.d. \\
\hline F1077 & 6 & $\mathrm{~F}$ & 34 & n.d. \\
\hline
\end{tabular}

'Registry' refers to our internal numbering system for study patients. 'Age' is the age at time of blood collection. 'Sex' refers to Male or Female. As listed, Endostatin serum levels are reported in $\mathrm{ng} / \mathrm{ml}$. The list of abbreviations for other abnormalities is as follows: -: no notable physical abnormalities; n.d.: detailed clinical history not available, but subject healthy at time of collection; AAl: atlantoaxial instability; AC: Arachnoid cyst; AP: annular pancreas; ASD: atrial septal defect; AUM: atopic urethral meatus; $B C O$ : bilateral crypto-orchiditis; C1AAH: $\mathrm{C} 1$ anterior arch hypoplasia; CS: cervical stenosis; DA: duodenal atresia; DM: diabetes mellitus; OS: oesophageal stenosis; GERD: gastro-oesophageal reflux disease; HT: hypothyroidism; HST: Hashimoto's Thyroiditis; MVP: mitral valve prolapse; OCSD: occult cervical spina bifida; PVI: pulmonic valvular insufficiency; SGB: septate gall bladder; SC: scoliosis; TVI: tricuspid valvular insufficiency; UC: ulcerative colitis; VSD: ventricular septal defect

endostatin levels with age in the control group and patient population studied revealed no significant correlation of endostatin level with age (F ratio 3.875, $P>0.05$ for both groups). Therefore, based upon the data presented in Figure 1 and Tables 1 and 2, we demonstrate that serum levels of 


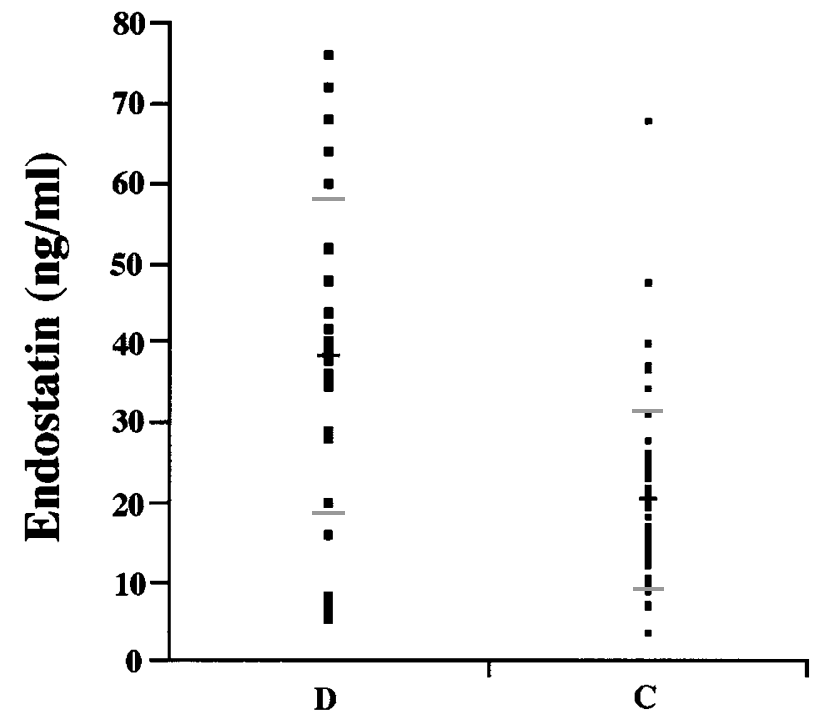

Figure 1 Endostatin serum levels in DS patients (D) and control subjects (C), which were determined through ELISA using a commercially available assay (Accucyte, Cytimmune Sciences, Inc., College Park, MD, USA). Dark horizontal bar represents the mean of endostatin levels; grey horizontal bar represents the standard deviation of endostatin values.

Table 2 Endostatin levels by sex

\begin{tabular}{lcc}
\hline Group & $F$ & $M$ \\
\hline Controls & & \\
$n$ & 32 & 22 \\
mean \pm S.D. & $20.7 \pm 13.6$ & $19.3 \pm 7.3$ \\
Downs & 19 & 16 \\
$n$ & $35.7 \pm 17.3$ & $42.3 \pm 22.6$ \\
$\quad$ mean \pm S.D. & 51 & 38 \\
Pool & $26.5 \pm 16.6$ & $29.0 \pm 19.2$ \\
$n$ & mean \pm S.D. &
\end{tabular}

F=female subjects; $M=$ male subjects; $n=$ number of subjects in each group; mean \pm S.D.=mean endostatin levels by sex for each group \pm standard deviation. Data reported in $\mathrm{ng} / \mathrm{ml}$ of serum. Controls=normal control individuals; Downs=Down Syndrome patients; Pool=normal control individuals and Down Syndrome patients pooled, then separated by sex

endostatin are significantly elevated in patients with DS as compared with a normal control population.

\section{Discussion}

The great variability of endostatin levels found both in controls and DS patients is in agreement with previous measurements of serum endostatin. ${ }^{17-19}$ We did not observe any effect of sex or age in serum endostatin levels both in controls and in DS patients, a finding that has not previously been reported.
Given the recent profusion of data about the effectiveness of endostatin as an antitumour agent in both human subjects and animal models, we propose that elevated serum levels of endostatin present in the serum of patients with DS might explain the relatively low incidence of many different types of solid tissue tumours in these patients.

Our data are compatible with recent experiments in mouse models, which showed that persistently high serum levels of endostatin resulted in a significant reduction of the tumour growth rate and in the prevention of micrometastases of some carcinomas. ${ }^{11,12}$ Based upon data presented here, we propose that an increase of about one-third of endostatin serum levels would be sufficient to significantly inhibit many solid tumour cancers. These results also predict that individuals in the population with serum endostatin levels higher than $20 \mathrm{ng} / \mathrm{ml}$ might be less prone for the development of solid tumours than those with lower levels and therefore, it will be important to evaluate the use of endostatin levels as a predictive test. It has recently been shown that reduced endostatin levels correlate with increased tumour size and higher histological grade of some types of tumour, thus reinforcing our hypothesis. ${ }^{17,18}$

Recently, several reports have been published about the mechanism of action of endostatin as an anti-angiogenesis and tumour suppressor reagent. ${ }^{20-22}$ It has been shown that endostatin acts directly and specifically upon endothelial cells in culture to produce intracellular signals such as the influx of extracellular $\mathrm{Ca}^{2+}$ into endothelial cells to produce elevated intracellular $\mathrm{Ca}^{2+}$ levels. ${ }^{20,21}$ Shichiri and Hirata ${ }^{20}$ were able to further demonstrate that endostatin application downregulates genes expressed during endothelial cell growth, and exhibited a potent antimigratory effect on endothelial cells in vitro, mediated through c-myc downregulation. Most recently, Karumanchi et $a l^{22}$ were able to use expression cloning to identify cell surface glypicans as a low affinity receptor for endostatin. Glypicans were shown to have functional relevance in antisense experiments using kidney cell lines, and in addition were also demonstrated to be highly expressed in epithelial cells. ${ }^{22}$ Therefore, taking together recent evidence, we can hypothesise that endostatin acts upon one or more receptors present on endothelial cells, resulting in intracellular signalling which decreases the migratory capacity and/or proliferative ability of endothelial cells, which prevents new vascularisation in the presence of high endostatin activity.

We further propose that rodent models of DS that would express elevated serum levels of endostatin could be used to test our hypothesis with regard to tumour incidence, and to test for any possible toxic effects of persistently high endostatin levels. High levels of circulating endostatin have been found in patients with Systemic Sclerosis, but it is still unclear if increased endostatin production is primary or secondary to the vascular injuries responsible for this condition. ${ }^{19}$ However, the elevated levels of endostatin found to associate with Systemic Sclerosis were five times 
greater than the normal subject controls, whereas in our study the increase in circulating endostatin in DS was much more modest. ${ }^{19}$ Despite the potential caveats, we believe that confirmation of a role for elevated serum endostatin levels as a protective agent for the lifelong development of solid tumours may lead to further advances in the understanding of endostatin antitumour activity and to improvement in cancer treatment.

\section{Acknowledgements}

We thank all the DS patients and the Hospital Darcy Vargas for collaboration, Dr. Sérgio Mattioli for helpful discussions in statistical analysis and Fundação de Amparo a Pesquisa do Estado de São Paulo (FAPESP) for financial support. MRPB is partly funded by an International program of the Howard Hughes Medical Institute.

\section{References}

1 Epstein CJ: Down syndrome (trisomy 21); in Scriver CR, Beaudet AL, Sly WS, Valle D (eds): The Metabolic and Molecular Bases of Inherited Disease. New York, 1995, vol 1, pp 749-794.

2 Satgé D, Sommelet D, Geneix A, Nishi M, Malet P, Vekemans M: A tumor profile in Down Syndrome. Am J Med Genet 1998; 78: $207-216$.

3 Hasle H, Clemmensen IH, Mikkelsen M: Risks of leukaemia and solid tumours in individuals with Down's syndrome. Lancet 2000; 355: $165-169$.

4 Satgé D, Sasco AJ, Carlsen NLT et al: A lack of neuroblastoma in Down Syndrome: A study from 11 European countries. Cancer Res 1998; 58: 448 - 452.

5 Hattori M, Fujiyama A, Taylor TD et al: The DNA sequence of human chromosome 21 . The chromosome 21 mapping and sequencing consortium. Nature 2000; 405: 311-319.

6 Sakata K, Tamura G, Nishizuka S et al: Commonly deleted regions on the long arm of chromosome 21 in differentiated adenocarcinoma of the stomach. Genes Chromosomes Cancer 1997; 18: $318-321$.

7 Ohgaki K, Iida A, Kasumi F et al: Mapping of a new target region of allelic loss to a $6-\mathrm{cM}$ interval at $21 \mathrm{q} 21$ in primary breast cancers. Genes Chromosomes Cancer 1998; 23: 244-247.

8 Schwendel A, Richard F, Langreck $\mathrm{H}$ et al: Chromosome alterations in breast carcinomas: frequent involvement of DNA losses including chromosomes $4 \mathrm{q}$ and 21q. $\mathrm{Br}$ J Cancer 1998; 78: 806-811.

9 ÓReilly MS, Boehm T, Shing Y et al: Endostatin: an endogenous inhibitor of angiogenesis and tumor growth. Cell 1997; 88: $277-285$.
10 Muragaki Y, Timmons S, Griffith CM et al: Mouse Col18a1 is expressed in a tissue-specific manner as three alternative variants and is localized in basement membrane zones. Proc Natl Acad Sci USA 1995; 92: 8763-8767.

11 Sauter BV, Martinet O, Zhang WJ, Mandeli J, Woo SL: Adenovirus-mediated gene transfer of endostatin in vivo results in high level of transgene expression and inhibition of tumor growth and metastases. Proc Natl Acad Sci USA 2000; 97: 48024807.

12 Feldman AL, Restifo NP, Alexander HR et al: Antiangiogenic gene therapy of cancer utilizing a recombinant adenovirus to elevate systemic endostatin levels in mice. Cancer Res 2000; 60: $1503-1506$.

13 Saarela J, Rehn M, Oikarinen A, Autio-Harmainen H, Pihlajaniemi T: The short and long forms of type XVIII collagen show clear tissue specificities in their expression and location in basement membrane zones in humans. Am J Path 1998; 253: $611-626$

14 Sertie AL, Sossi V, Camargo AA, Zatz M, Brahe C, Passos-Bueno MR: Collagen XVIII, containing an endogenous inhibitor of angiogenesis and tumor growth, plays a critical role in the maintenance of retinal structure and in neural tube closure (Knobloch syndrome). Hum Mol Genet 2000; 9: 2051-2058.

15 Felbor U, Dreier L, Bryant RA, Ploegh HL, Olsen BR, Mothes W: Secreted cathepsin $\mathrm{L}$ generates endostatin from collagen XVIII. EMBO J 2000; 19: 1187 - 1194

16 Sasaki T, Fukai N, Mann K, Gohring W, Olsen BR, Timpl R. Structure, function and tissue forms of the C-terminal globular domain of collagen XVIII containing the angiogenesis inhibitor endostatin. EMBO J 1998 ;17: 4249 - 4256.

17 Musso O, Rehn M, Theret $\mathrm{N}$ et al: Tumor progression is associated with a significant decrease in the expression of the endostatin precursor collagen XVIII in human hepatocellular carcinomas. Cancer Res 2001; 61: 45-49.

18 Feldman AL, Tamarkin L, Paciotti GF et al: Serum endostatin levels are elevated and correlate with serum vascular endothelial growth factor levels in patients with stage IV clear cell renal cancer. Clin Cancer Res 2000; 6: 4628-4634.

19 Hebbar M, Peyrat J-P, Hornez L, Hatron P-Y, Hachulla E, Devulder B: Increased concentrations of the circulating angiogenesis inhibitor endostatin in patients with Systemic Sclerosis. Arth Rheum 2000; 43: 889-893.

20 Shichiri M, Hirata Y: Antiangiogenesis signals by endostatin. FASEB J 2001; 15: $1044-1053$

21 Jiang L, Jha V, Dhanabal M, Sukhatme VP, Alper SL: Intracellular $\mathrm{Ca}^{2+}$ signaling in endothelial cells by the angiogenesis inhibitors endostatin and angiostatin. AJP Cell Physiol 2001; 280: C1140-C1150.

22 Karumanchi SA, Jha V, Ramchandran $\mathrm{R}$ et al: Cell surface glypicans are low-affinity endostatin receptors. Mol Cell 2001; 7: $811-822$. 